\title{
Effect of Fermentation Time and Calcium Nitrate Concentration on Enzyme Glucoamylase Production of Gliocladium KE Using Sago Hampas Solid Substrate
}

\author{
Risa Meutia Fiana ${ }^{1}$, Novelina ${ }^{2}$ and Alfi Asben ${ }^{2}$ \\ ${ }^{1}$ Agroindustrial Technology Study Program, Andalas University \\ E-mail: risameutia@ymail.com \\ ${ }^{2}$ Department of Agricultural Product Technology, Faculty of Agricultural Technology, Andalas University \\ E-mail:novelinasusanto@yahoo.com; alfi_asben@yahoo.com
}

\begin{abstract}
This research aims to obtain the appropriate fermentation time and suitable concentration of calcium nitrate (Ca (NO3) 2) which is suitable with minerals solution used for sago hampas as a solid substrate to produce optimal activity of glucoamylase. This study was conducted in two stages. The first stage is to apprehend the fermentation time of Gliocladium KE fungal on solid substrates to produce optimal glucoamylase enzyme activity. Fermentation was conducted in 6 days, which each day is measured enzyme activity of glucoamylse and counted the number of spores of Gliocladium KE. The second stage is to get the optimal concentration of calcium nitrate was added to the mineral solution on a solid substrate of sago hampas to produce the highest glucoamylase. The concentration of calcium nitrat used was $2.57 \mathrm{~g}, 3.57 \mathrm{~g}$ and $4 . .57 \mathrm{~g}$. The results showed that the fermentation for 4 days produced the highest glucoamylase enzyme activity of 24.22 units / mL by the number of spores $2.7 \times 108 \mathrm{spores} / \mathrm{mL}$. The concentration of calcium nitrat on 3:57 $\mathrm{g}$ with fermentation for 4 days resulted in the highest enzyme glucoamylase.
\end{abstract}

Keywords - Glucoamylase; Gliocladium KE; Sago Hampas; Fermentation Time; Calsium Nitrate

\section{INTRODUCTION}

Waste processing sago palm, especially ,sago waste has been utlilized optimally utilized and only a small portion is used as feed, especially ruminants, whereas it is quite large potential, especially in Papua, Sulawesi and Sumatera. Sago waste contains critical components such as starch and cellulose $^{[5]}$. Total waste of sago bark approaching $26 \%$, while sago residue around $14 \%$ of the total weight of custody sago. Sago waste contains $65.7 \%$ starch and the rest of it are crude fiber, crude protein, fat, and ash.

Glucoamylase is an enzyme that hydrolyze units from poly- or olygosacarida to produce glucose ${ }^{[8]}$. Glucoamylase has been extensively used in starch processing industries, and because of its importance, so that a lot of numerous fungal glucoamylase have been studied ${ }^{[9]}$. Glucoamylase from Gliocladium $K E$ has been found as a new discovery of glucoamylase enzyme from fungi.

Addition of inorganic nitrogen source into the substrate will influence on the productivity of the glucoamylase. Glucoamylase production on solid medium can be improved the productivity by adding inorganic nitrogen sources ${ }^{[10]}$. This is due to the addition of inorganic nitrogen can accelerate the growth of biomass in which the rapid growth of the biomass will stimulate the formation of the enzyme glucoamylase ${ }^{[11]}$. Nitrate ions $\mathrm{Ca}\left(\mathrm{NO}_{3}\right)_{2}$ is widely used by microorganisms as a source of nitrogen. $\mathrm{Ca}$ $\left(\mathrm{NO}_{3}\right)_{2}$ is an excellent source of nitrogen for the growth of fungi ${ }^{[6]}$ beside that being a source of nitrogen $\mathrm{Ca}\left(\mathrm{NO}_{3}\right)_{2}$ also serves as a source of calcium in the substrate. Calcium influences growth and process to produce secondary metabolites from Gliocladium, $K E^{[7]}$. This research aims to obtain the appropriate fermentation time and suitable concentration of calcium nitrate $\left(\mathrm{Ca}\left(\mathrm{NO}_{3}\right)_{2}\right)$ on medium minerals for sago hampas a solid substrate to produce optimal activity of glucoamylase. The study was conducted in two stages. The first stage is to apprehend the fermentation time of Gliocladium KE fungal on solid substrates to produce optimal glucoamylase enzyme activity. Fermentation was carried out for 6 days, where each day is measured enzyme activity of glucoamylse and counted the number of spores of Gliocladium KE. 


\section{MATERIAL AND METHODS}

\section{A. Material}

Microorganisms used in this study are Gliocladium isolates which the culture collection of the Laboratory of Microbiology and Biotechnology Faculty of Agricultural Technology. The materials used as isolate refreshment is Potato dextrose agar (PDA) merck. Materials for sago cultivation is the dregs from Pariaman (Subarang-Ciparuh) that has been mashed and pass 80 mesh sieve, distilled water, filter paper, buffer fospat, $\mathrm{Ca}$ (NO3) 2 (Merck), MgSO4.7H2O (Merck), Na-acetate, Tween 80, a solution of DNS, $\mathrm{Pb}$ acetate, $\mathrm{Na}$ Fospat $8 \%, 5 \%$ phenol and $\mathrm{H} 2 \mathrm{SO} 4$ (Merck).

\section{B. Method of Research}

The Methods used in this study through two stages, first stage is a preface research and the second stage is the main research. The preface research consist of drying sago hampas, shringking size sago hampas until get through a sieve 80 mesh and analyze the raw material.

The main research have two stages research, the first stage is the decision time of optimal fermentation and the second stage is the decision of the mineral solution concentration $\mathrm{Ca}\left(\mathrm{NO}_{3}\right)_{2}$ to accurate the glucoamylase production. This research used 3 replication that are :

a. The First Stage : the decision time of optimal fermentation.

A 1 : Long Time Fermentation 24 hours

A 2 : Long Time Fermentation 48 hours

A 3 : Long Time Fermentation 72 hours

A 4 : Long Time Fermentation 96 hours

A 5 : Long Time Fermentation 120 hours

A 6 : Long Time Fermentation 144 hours

b. The Second Stage : The Mineral Solution Concentration $\mathrm{Ca}\left(\mathrm{NO}_{3}\right)_{2}$

B 1 : added $\mathrm{Ca}\left(\mathrm{NO}_{3}\right)_{2} 2,57 \mathrm{~g}$

B 2 : added $\mathrm{Ca}\left(\mathrm{NO}_{3}\right)_{2} 3,57 \mathrm{~g}$

B 3 : added $\mathrm{Ca}\left(\mathrm{NO}_{3}\right)_{2} 4,57 \mathrm{~g}$

The observation for the optimal fermentation time are spores's quantity with Haemocytometer method and glucoamylase activity with Sunaryanto method. For a treatment concentration the mineral solution $\mathrm{Ca}\left(\mathrm{NO}_{3}\right)_{2}$, it was observed the glucoamylase activity.

\section{Method of Execution}

1) Isolates of Gliocladium Refresher: Refresher isolates is done by moving the mold to culture in a petri dish containing PDA media. Subsequently it incubated for 4 days at a temperature of $27-28^{\circ} \mathrm{C}$. After growing colonies, each colony was transferred on aslant agar and each colony were coded.

2) Driying Of Sago Hampas: Sago hampas drying used solar dryers untill $12 \%$ moisture content of material. Drying is done by laying the sago waste in the solar dryer.

3) Shrinking Size: Sago hampas size reduction is done using a blender. After blended dregs sifting sago using 80 mesh size sieve. Sago dregs which not passed 80 mesh sieve, its blended again until sago waste 80 mesh sieve size.
4) Substrate Preparation and Production of Glucoamylase: Substrates used in this study refers to the composition which is used by Tani et, al (1986) cit Sunaryanto, 2003, modified. The composition is as follows: $57.82 \mathrm{~g}$ Dregs sago, $1.67 \mathrm{~g}$ $\mathrm{MgSO} 4.7 \mathrm{H} 2 \mathrm{O}, \mathrm{Ca}$ (NO3) 2 according to treatment, and 37 $\mathrm{mL}$ of water. All fermentation medium in erlenmeyer 500 $\mathrm{mL}$ is sterilized by autoclave at $121^{\circ} \mathrm{C}$ for 15 minutes. Gliocladium KE inoculation into fermentation medium is conducted by using Gliocladium KE suspense in $0.1 \%$ (v/ v) tween 80 into as many as $9 \mathrm{ml}$ distilled water. Hereafter it is done by fermenting in erlemeyer with aerobic conditions at a temperature of $27-30^{\circ} \mathrm{C}$ for 4 days.

\section{5) Extraction and Production of Crude Enzyme} Glucoamylase (modification Sunaryanto, 2003): Extraction is done by adding acetate buffer $\mathrm{pH} 4.6$ for 3 times of the weight solid substrate fermentation, then stirred for 30 minutes at $4^{\circ} \mathrm{C}$. Subsequently centrifuged at a speed of $11,000 \times \mathrm{G}$ for $10 \mathrm{~min}$ and filtered. The filtrate obtained is called the crude enzyme. Filttrat extracted enzyme was precipitated by adding isopropanol solvent organic that has been cooled in a freezer at a temperature of $-4^{\circ} \mathrm{C}$. The filtrate was mixed with an organic solvent, the solvent volume of isopropanol was added to the filtrate from the filtrate as much as 1.67 times from the concentration of enzyme or $60 \%(\mathrm{v} / \mathrm{v})$. The addition of organic solvents is done smoothly. Once mixed with an organic solvent and then stored in a cold room at $4{ }^{\circ} \mathrm{C}$ for 24 hours. Hereafter it's done $11,000 \times \mathrm{G}$ centrifugation for 10 minutes at $4{ }^{\circ} \mathrm{C}$. Then separated precipitate with the filtrate. Precipitated enzyme added acetate buffer $\mathrm{pH} 4.6$ to obtain a crude enzyme extract glucoamylase.

6) Glucoamylase Activity: Crude enzyme extracted was filtered through cotton and then centrifuged at $1000 \mathrm{rpm}$ at 4 ${ }^{\circ} \mathrm{C}$ over the temperature as much as $1 \mathrm{ml}$ pipetted into a test tube. After the crude enzyme extracted then added $2 \mathrm{ml}$ pipetted acetate buffer $\mathrm{pH}$ 4.6.For the enzyme extract control, it's incubated first at $100{ }^{\circ} \mathrm{C}$ for 5 minutes. Then taken 0.1 $\mathrm{ml}(\mathrm{Vc})$ of the mixture move into another test tube and add $1.9 \mathrm{ml}(\mathrm{Vsb})$ of $2 \%$ soluble starch. Do stirring so flat after it is heated at a temperature of $60{ }^{\circ} \mathrm{C}$ for 20 minutes $(\mathrm{t})$. After heating the sample will be divided into two parts, at the top it will look transparent and cloudy at the bottom. The lucid samples were pipetted. Analysis is done by adding $0,5 \mathrm{ml}$ samples of $1.5 \mathrm{ml}$ DNS. After the sample is mixed with a solution of control samples then boiled for 5 minutes. After that the sample was cooled with flowing water. The cooled sampel is pipetted as much as $0.4 \mathrm{ml}$ of distilled water and then added to the mix until homogeneous. Then conducted the measurement of reducing sugar (Cgr) on absorbance 540 $\mathrm{nm}$. To form the cooperation procedure with sample working procedures but samples exchanged with acetate buffer $\mathrm{pH}$ 4.6. Glucoamylase activity can be measured by the following formula:

$$
\text { Glucoamylase Activity }=\underline{\operatorname{Cgr} x(V c+V s b) \times F p}
$$




\section{RESULT AND DICUSSION}

Sago starch residue levels are still high and the potential for growth in the KE Gliocladium and produce glucoamylase, this can be seen in Table 1 .

TABLE I

CHEMICAL COMPOSITION OF SAGO HAMPAS

\begin{tabular}{ll}
\hline Component & Content (\%) \\
\hline Starch & $54,35 \%$ \\
Protein Level & $3 \%$ \\
Ash Content & $3,32 \%$ \\
Fat Content & $0,13 \%$ \\
\hline
\end{tabular}

Starch were high enough and it contained in the sago waste utilized by Gliocladium KE as a carbon source. The starch is splitted into simple sugars by microorganisms into glucose, then glucose is utilized by microorganisms into carbon sources by removing extracellular enzyme glucoamylase. The content of sago waste dregs sago starch obtained results are also high at $65.7 \%{ }^{[6]}$. The chemical composition of soluble starch observed were the early starch content at $2,12 \%$.

\section{A. Decision time of optimal fermentation for Producing glucoamylase}

Isolates of Gliocladium isolates idegeneous is still new and the result of isolation on sago waste. Further identification to know the growth curve on the solid substrate of Gliocladium KE sago waste by using medium Tani et al. Gliocladium KE which is grown in solid substrate sago waste, measured the number of spores per day for 6 days using a haemocytometer. The results of measurement of the number of spores growth of Gliocladium $K E$ and glucoamylase activity portrayed in the number of spores growth curve as follows:

TABLE II

NUMBER OF SPORES GLIOCLADIUM KE AND GLUCOAMYLASE ACTIVITY

\begin{tabular}{clc}
\hline $\begin{array}{c}\text { Time } \\
\text { (hours) }\end{array}$ & $\begin{array}{l}\text { Numbers of Spores } \\
\text { (Spores/ml) }\end{array}$ & $\begin{array}{c}\text { Glucoamylase } \\
\text { Activity }(\mathbf{U} / \mathbf{m l})\end{array}$ \\
\hline A.1 $(24)$ & $1,3 \times 10^{8}$ & 5,11 \\
A.2 (48) & $1,5 \times 10^{8}$ & 12,99 \\
A.3 (72) & $2,0 \times 10^{8}$ & 21,83 \\
A.4 (96) & $2,7 \times 10^{8}$ & 24,22 \\
A.5 (120) & $2,5 \times 10^{8}$ & 22,20 \\
A.6 (144) & $1,5 \times 10^{8}$ & 17,44 \\
\hline
\end{tabular}

Gliocladium $K E$ growth curve used to determine the future growth of Gliocladium $K E$ that will be used as a reference in the best fermentation extracts crude enzyme glucoamylase. Glucoamylase activity of a solid substrate sago hampas is measured from 24 hours to 144 hours. Glucoamylase activity were highest on 96 hours produced glucoamylase activity of $24.22 \mathrm{U} / \mathrm{ml}$.

In the hour-to-hour 0 to 24 is the adaptation phase, in this phase Gliocladium $K E$ adapting to a new medium that is medium to solid substrates sago waste., On the 48 hour to hour-72 is exponential phase, the phase eksponesial seen increased cell number At the $96 \mathrm{hr}$ hour until the stationary phase where 120 is shown in Table 2. Seen the number of spores Gliocladium KE at the 96 hours to- 120 is not too far away. At 144 to indicate the phase of death, which at 144 hours Gliocladium KE declining number of spores. Contend phase is the phase of adaptation of microorganisms to adapt to the new environment ${ }^{[4]}$. Eksponesial phase is a phase of very rapid multiplication of cells, at the end of this phase of the enzymes can be harvested ${ }^{[4]}$. Stationary phase is the number of cells increases balanced by the number of cells that die, a lot of secondary metabolites that can be harvested at the beginning of this phase ${ }^{[4]}$. In the death phase of the cell number of dead will rise ${ }^{[4]}$.

Determination of optimum fermentation time by determining the ampleness of glucoamylase activity with an interval of 24 hours for 6 days. The production of the enzyme in a bioprocess requires a number of factors among other is the growth curve and optimum conditions to increase the activity of the enzyme ${ }^{[3]}$. Optimum activity in generating Gliocladium KE glucoamylase at 96 hours was $24.22 \mathrm{U} / \mathrm{ml}$. If seen from the number of spores between the $96^{\text {th }}$ hour to nearly $120^{\text {th }}$ the number of spores which are respectively $2.7 \times 10^{8}$ and $2.5 \times 10^{8}$ spores / ml. It can be concluded that the 96th hour have entered the early stationary phase. At the beginning of the stationary phase produces the highest glucoamylase activity. The enzyme synthesis extracellular in the largest number normally occurs at the end of the exponential phase and early stationary phase ${ }^{[1]}$. The situation is due to the exponential transition phase followed by decreasing carbon source in the medium, so that the synthesis of enzymes began to rise.

\section{B. The Mineral Solution Concentration of $\mathrm{Ca}\left(\mathrm{NO}_{3}\right)_{2}$}

The treatment conducted in the production of glucoamylase is mineral concentration $\mathrm{Ca}\left(\mathrm{NO}_{3}\right)_{2}$ on the solid substrate sago waste. The observations made to apprehend the influence of mineral concentration $\mathrm{Ca}\left(\mathrm{NO}_{3}\right)_{2}$ as a crude enzyme extract glucoamylase activity. The results of these observations are as follows:

TABLE III

EFFECT OF MINERAL SOLUTION CA (NO3) 2 ON GLUCOAMYLASE ACTIVITY

\begin{tabular}{lc}
\hline Treatment & $\begin{array}{c}\text { Glucoamylase } \\
\text { Activity ( U/ml) }\end{array}$ \\
\hline B.1 (added $\left.\mathrm{Ca}\left(\mathrm{NO}_{3}\right)_{2} 2,57 \mathrm{~g}\right)$ & 20,41 \\
B.2 (added $\left.\mathrm{Ca}\left(\mathrm{NO}_{3}\right)_{2} 3,57 \mathrm{~g}\right)$ & 37,23 \\
B.3 (added $\left.\mathrm{Ca}\left(\mathrm{NO}_{3}\right)_{2} 4,57 \mathrm{~g}\right)$ & 27,21 \\
\hline
\end{tabular}

In Table 3. Described the glucoamylase activity of the crude enzyme extract were the highest in the addition of a solution of mineral treatment $\mathrm{Ca}\left(\mathrm{NO}_{3}\right)_{2}$ with a concentration of $3.57 \mathrm{~g}$ of as much as $37.23 \mathrm{u} / \mathrm{ml}$. In the addition of $\mathrm{Ca}\left(\mathrm{NO}_{3}\right)_{2}$ with concentration of $4.57 \mathrm{~g}$ glucoamylase activity decreased. Glucoamylase activity measured on the addition of $\mathrm{Ca}\left(\mathrm{NO}_{3}\right)_{2} \quad 4.57 \mathrm{~g}$ as much as $27.21 \mathrm{U} / \mathrm{ml}$. Mineral solution concentration of $\mathrm{Ca}\left(\mathrm{NO}_{3}\right)_{2}$ which gave optimal results for glucoamylase activity was $3.57 \mathrm{~g}$.

The addition of other nutrients such as nitrogen source into the substrate needed to support cell growth and 
secondary metabolites. Decreasing in glucoamylase activity can occur because of the concentration of nitrogen is too high so that it accelerates the growth of Gliocladium KE. The addition of inorganic nitrogen can accelerate the growth of biomass in which the rapid growth of the biomass will stimulate the formation of glucoamylase ${ }^{[11]}$. Nitrogen serves to accelerate cell growth in fermentation media ${ }^{[12]}$.

In addition to sources of nitrogen, calcium contained in $\mathrm{Ca}\left(\mathrm{NO}_{3}\right)_{2}$ also has an influence in the growth of Gliocladium KE. The suitable conditions on giving calcium $\mathrm{Ca}\left(\mathrm{NO}_{3}\right)_{2}$ as much as $3.57 \mathrm{~g}$. The addition of calcium can increase the production of enzymes and increase enzyme activity also generated. The production of glucoamylase by the addition of calcium can produce glucoamylase activity higher than the medium without calcium ${ }^{[2]}$.

Concentration of $\mathrm{Ca}\left(\mathrm{NO}_{3}\right)_{2}$ in the limit sufficient to increase the production of glucoamylase, but excessive amounts can be a barrier for the growth of Gliocladium KE in producing glucoamylase. Inhibition occurs because $\mathrm{Ca}\left(\mathrm{NO}_{3}\right)_{2}$ can be toxic to Gliocladium $K E$ if the amount is excessive. An important mineral is added to the medium, but if it's very high mineral concentration can inhibit the growth to be toxic to fungi and molds itself ${ }^{[7]}$. At a concentration of $\mathrm{Ca}\left(\mathrm{NO}_{3}\right)_{2} 4.57 \mathrm{~g}$ of a high concentration of minerals for Gliocladium $K E$ cause impaired growth and inhibit the formation of the enzyme glucoamylase glukoamilase activity is higher than the medium without calcium.

\section{CONCLUTION}

Glucoamylase fermentation time of Gliocladium KE using sago waste has the highest activity on 96 hours with glucoamylase activity generated at $24.22 \mathrm{U} / \mathrm{ml}$ and the amount number of spores $2.7 \times 10^{8}$ spores $/ \mathrm{ml}$. The mineral solution concentration of $\mathrm{Ca}$ (NO3) 2 is added to the substrates optimally dense sago waste in producing glucoamylase was $3.57 \mathrm{~g}$ with glucoamylase activity of $37.23 \mathrm{U} / \mathrm{ml}$.

\section{REFERENCE}

[1] Anwar, K. Optimasi dan Aktivasi Enzim Selulase dari Mikrob Selulolitik Asal Rayap. Fakultas Matematika dan Ilmu Pengetahuan Alam Institut Pertanian Bogor. Bogor. 2008.

[2] Asghar, M., Sunaryanto R., Umbreen A., M. J. Asad. Kinetics of Glucoamylase Production by Arachniotus sp. Departement of Chemistry Universitas of Agriculture. Pakistan. 2002.

[3] Fardiaz, S. Fisiologi Fermentasi. Pusat Antara Universitas Pangan dan Gizi, Institut Pertanian Bogor. Bogor. 1988.

[4] Gandjar, I., Wellyzar, S., Ariyanti, O. 2006. Mikologi Dasar. Yayasan Obor Indonesia. Jakarta.

[5] Kiat, L. J. Preparation and Characterization of Charboxymethil Sago Waste Hydrogel. Master of Science University Putra Malaysia. Malaysia. 2006.

[6] Kibar, B and Aysun P. Mycelia Growth Requirements of Lactarius pyrogalus and Lactarius controversus. African Journal of Microbiology Research. Afrika. 2011.

[7] Kubichek, M. E. Nutrition, Cellular Structure and Basic Metabolic Pathway Tricodherma and Gliocladium. Taylon and Francis eLibrary. 2002.

[8] Makfoeld, D., Djagal W., Pudji, A., Sri, A., Sri, R., Sudharmanto, S., Suhardi., Soeharsono, M., Suwedo., and Trangono. Kamus Istilah Pangan dan Nutrisi. Kanisius. Yogyakarta. 2002.

[9] Siddhartha, C, L., Sridevi., and Manasa. Glucoamylases: Types, Microbial Sources And Potential Applications - a Review [jurnal].
International Journal of Science Innovations and Discoveries ISSN:2249-5347. 2012.

[10] Sunaryanto, R. Pengaruh Kombinasi Media Sumber Karbon (Dedak : Tapioka) Dan Sumber Nitrogen Pada Kultivasi Media Padat Produksi Enzim Glukoamilase. Prosiding Seminar Nasional Rekayasa Kimia Dan Proses 2004 ISSN : 1411 - 4216. 2003.

[11] Pemisahan Enzim Glukoamilase dari Kaldu Fermentasi Menggunakan Membran Utrafiltasi [jurnal]. Prosiding Seminar Nasional Rekayasa Kimia Dan Proses Issn : 1411 - 4216. 2004

[12] Trismilah and Sunaryanto. 2005. Pengaruh Kadar Nitrogen pada Media Pembuatan Protease Menggunakan Bacillus megaterium DSM 319. Jurnal Ilmu Kefarmasian Indonesia. Jakarta. 2006. 